\title{
El Autor no ha muerto
}

Marcos Moscoso Garay ${ }^{*}$

University of British Columbia

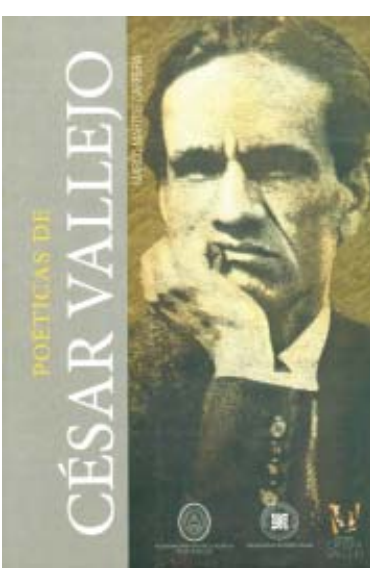

Poéticas de César Vallejo

Marco Martos Carrera

Lima: Editorial Cátedra Vallejo, 2. ed. (Archivo Vallejo N. 1, colección dirigida por Gladys Flores Heredia)

Año: $2014,120 \mathrm{pp}$.

ISBN: 978-612-46689-2-0

marcos.moscoso@alumni.ubc.ca

Pues es ese que se dice poeta, ese César Vallejo, un hombre a quien le falta un tornillo...

Ciro Alegría, El César Vallejo que yo conocí

\begin{abstract}
Dienen realmente los creadores un estatuto privilegiado a la hora de ejercer crítica literaria? Para Ricardo Silva Santisteban la respuesta es afirmativa. En el prólogo del libro Poéticas de César Vallejo, de Marco Martos, expresa que la crítica de un creador es mucho más interesante, más perceptiva y profunda, por ello, más duradera. Entonces, Marco Martos sería un buen ejemplo de ello. Sea o no cuestionable dicha afirmación, sobre todo, si se quiere sentar a la crítica literaria sobre bases epistemológicas o gnoseológicas; lo cierto es que el presente libro reseñado a continuación, es un interesante conjunto de

\footnotetext{
Marcos Moscoso Garay estudió Literatura en la Universidad Nacional Mayor de San Marcos. Es máster en Literatura Hispánica, Historia, Arte y Sociedad por la Universidad Autónoma de Madrid (España). Actualmente, es aspirante a Doctor of Philosophy in Hispanic Studies por la University of British Columbia (Canadá).
} 
ensayos que fueron presentados en diferentes coloquios, conferencias y artículos sobre algunos aspectos de la poesía de César Vallejo.

El primer artículo, "Primero vivir, después filosofar", fue leído en el VIII Congreso Fronteras del Psicoanálisis: Nuevas miradas, en el 2003. Martos comienza señalando las preocupaciones del hombre moderno por construir nuevos sistemas totales que lo ayude a comprender el mundo debido a la decadencia ideológica de la religión. La causa de esto sería el desarrollo del racionalismo científico, el escepticismo y el secularismo explícito de la Ilustración.

Martos analiza, de manera general, las concepciones filosóficas de Marx, Freud, Lévi-Strauss y el poema "Un Hombre Pasa con un Pan al Hombro...”, de César Vallejo. Asimismo, hace un parangón entre la totalidad histórica y sincrónica de los sistemas filosóficos y lo específico en las vivencias del hombre cotidiano. Martos concluirá que estos movimientos filosóficos lo que tienen en común son la nostalgia de lo absoluto, una explicación global y detallada de las motivaciones de las conductas de los hombres; mientras que para César Vallejo, la preocupación es el hombre cotidiano que primero tiene que satisfacer las necesidades básicas, las cuales son más urgentes.

El segundo artículo, "César Vallejo y el don de la palabra", fue escrito a propósito de la conmemoración del 67 aniversario de la muerte de César Vallejo. Martos empieza resaltando la juventud de la literatura peruana frente a otras como la española, la inglesa o la italiana. Sostiene que en esta juventud, César Vallejo es el escritor que mejor representa al Perú y que se ha convertido ya en un clásico de la literatura universal. Con toda razón, Martos que que el nombre de César Vallejo se menciona con el mismo respeto que despiertan Quevedo o san Juan de la Cruz en la literatura española; Baudelaire o Rimbaud, en la literatura francesa; Quasimodo o Ungaretti, en la literatura italiana.

En el siguiente artículo, "Eielson y Vallejo: dos poetas clásicos de la lengua española", Marco Martos parte de la preocupación de salir de la subjetividad cuando se tiene que elegir, entre muchos poetas peruanos, el difícil estatuto de ser considerado poeta clásico. Entonces, establece algunos principios objetivos que le permiten sostener que tanto Eielson como Vallejo son dos poetas clásicos de la lengua española. Para Martos, la obra clásica se encuentra entre lo elemental y lo eterno, entre lo antiguo y lo permanente; hablan a su generación y también a la contemporaneidad. Teniendo en cuenta esto, Vallejo sería, entonces, el poeta más representativo de la lengua española y Eielson formaría parte de un grupo privilegiado de poetas que han escrito la más valiosa poesía del Perú en el siglo XX. 
El ensayo "El caballo en Vallejo y en la poesía peruana" fue presentado en las Jornadas de Literaturas latinoamericanas organizadas por la Universidad de Alicante, en Santander, el 2010. En dicho ensayo, Martos hace un rastreo de la imagen del caballo en la poesía peruana como una relación dialéctica particular con el hombre. Llega a interesantes conclusiones, por ejemplo, en torno a Manuel González Prada, quien veía a los caballos blancos como los sueños del hombre; Chocano, como epopeya del pasado; Eguren señala en el caballo el espíritu aristocrático que vive y muere en soledad mientras que Vallejo se hermana con el caballo.

Para Martos, Vallejo, de forma particular, considera al cuadrúpedo como parte cercana del ser humano, como un hermano con el que comparten los mismos sufrimientos y esperanzas. Aunque Martos sostiene que para encontrar la humanización del caballo habría que trasladarse a la antigua Grecia, pienso que basta con darse cuenta que la humanización de la naturaleza es parte importante de la mayoría de las culturas andinas como la Quechua. No es necesario, entonces, trasladarse hasta Homero para encontrar dicha relación.

En el artículo "Las identidades de Vallejo", Marco Martos propone la existencia de varías identidades en la obra de Vallejo, para ello hace un análisis minucioso del yo poético en toda la obra, desde Los Heraldos Negros hasta Poemas Humanos, para luego concluir que en la cultura andina peruana, en particular, la de los Andes del norte del país, está presente en las distintas identidades de César Vallejo. Vallejo, dice Martos, fue asumiendo distintas identidades a lo largo de toda su vida; identidades que no fue abandonando, sino sumando; la del serrano, la del inmigrante, la del marginal; todas ellas, para Martos, vivieron en perpetua convivencia.

Seguidamente, el primer tema que Marco Martos resalta en el estudio "Imágenes paternas en la poesía de César Vallejo" es que la imagen del padre lleva al tema religioso. Martos afirma que esto se ve con claridad, sobre todo, en Los Heraldos Negros, donde el tema de Dios es la proyección de las imágenes paternas, pero estas imágenes casi desaparecen de la poesía última debido al énfasis que pone al interés político. Martos utiliza en este ensayo, de manera ejemplificadora, los poemas de Jorge Eduardo Eielson y de Pablo Guevara, como introducción para estudiar las imágenes del padre en César Vallejo. Luego, ayudado por teorías psicoanalíticas, llega a la conclusión de que el hijo en Vallejo tiene distintas imágenes del padre que varían de acuerdo con los grados de madurez que va alcanzando el yo poético.

En el penúltimo artículo, “Cuatro conciencias’ y la eficacia de la poesía de César Vallejo”, ponencia leída en el Congreso César Vallejo, Telúrico y Magnético, en el 2012, se 
tratan puntos importantes tanto para la comprensión del Vallejo como teórico de su propio quehacer literario, como hombre presente y cuestionador de las importantes ideologías de su época, como fue el surrealismo. Martos concluye que con este poema Vallejo sale, de manera clara, al frente (bastante mejor que en su artículo "Autopsia de surrealismo", de 1930), a las propuestas teóricas de André Breton y sus amigos. Martos alega, notoriamente, que Vallejo, de ninguna manera, escribió a la usanza surrealista para ser analizado como si su escritura estuviera sentada en un diván.

Martos puntualiza que, mientras los surrealistas pregonaban la asociación libre de ideas, Vallejo, por otro lado, en toda su actividad literaria y, particularmente, en su escritura poética, tuvo orden y era consciente de su quehacer poético y así se observa en el poema "Cuatro conciencias". En consecuencia, concluye Martos, Vallejo habla de cinco conciencias que actúan, simultáneamente, que hacen temblar a los que las conocen. Entonces, contradiciendo, de manera efectiva, al surrealismo; Cesar Vallejo es el más consciente de los hombres, que en un solo haz junta vida consciente y vida inconsciente. En suma, el poeta es un hombre de conciencia múltiple.

Desde la perspectiva de la presente reseña, Vallejo reivindica la cotidianidad andina. El lugar de donde parten sus ideologías éticas, estéticas y políticas son desde la marginalidad, tanto de la identidad como del lenguaje. Y al transformar dicha marginalidad en un proyecto estético sumado a su genio creador enriqueció no solo la poesía peruana, sino también la universal.

Teniendo en cuenta los artículos comentados en esta reseña, es grato recomendar el libro Poéticas de César Vallejo, de Marco Martos, que se suma de manera creativa y solvente a los estudios que ocasiona y que seguirá ocasionando tan importante poeta. El nombre de César Vallejo, entonces, resuena como un trueno en la Literatura Universal y sigue presente y estará presente porque se ha convertido en un clásico de la literatura o, como dice Martos, la obra de Vallejo se comunica de modo intenso con miles y miles de lectores, de su momento histórico, del tiempo actual y seguramente del tiempo que vendrá. 
SIGNOS

\section{Referencias}

Alegría, C. (enero-abril, 2006). El César Vallejo que yo conocí. Argumentos 19(50), 81-95. Recuperado de <http://bidi.xoc.uam.mx/resumen_articulo.php?id=5\&archivo=115uyt.pdf\&titulo_articulo=El\%20C\%E9sar\%20Vallejo\%20que\%20yo\%20 conoc\%ED>

Martos, M. (2014). Poéticas de César Vallejo. Lima, Perú: Editorial Cátedra Vallejo. 